Journal of the Scholarship of Teaching and Learning, Vol. 17, No. 4, October 2017, pp. 31-43. doi: 10.14434/josotl.v17i4.21763

\title{
Assessing the Development of Civic Mindedness in a Cohort of Physical Therapy Students
}

\author{
Kerstin M. Palombaro, PT, PhD, CAPS \\ Widener University \\ kpalombaro@widener.edu \\ Jill D. Black, PT, DPT, EdD \\ Widener University \\ Robin L. Dole, PT, DPT, EdD, PCS \\ Widener University \\ Jessica L Pierce, PT, DPT \\ PowerBack Rehabilitation \\ Marisa R. Santiago, PT, DPT \\ Easter Seals
}

Edward J. Sabara, PT, DPT

Wallace and Nilan Physical Therapy and Fitness 


\begin{abstract}
Introduction and Background

Colleges and universities have an obligation to educate graduate students who demonstrate civic literacy and who can engage in civic inquiry and action. Servicelearning and community engagement courses are highly effective in developing civic-mindedness. Graduate professional programs may have additional reasons for focusing on development of civic mindedness. The purpose of this paper is 1) to measure the development of civic-mindedness increased in a cohort of physical therapy students exposed to a variety of civic engagement programs and servicelearning courses and 2) to determine if there is a difference in civic-mindedness between students serving on a pro bono clinic Student Board and their classmates in a graduate physical therapy program.

Methods

The Civic-Minded Professional Scale (CMP) is a 23-item, 7-point Likert-scale survey designed to measure the domains of self-identity; work, career and profession; and civic attitudes, civic action, and public purpose to measure the construct of civic-mindedness. The CMP was administered to a cohort of graduate physical therapy students at the beginning of the professional curriculum and at the end of each of three years of didactic coursework.

Results

Friedman's repeated measures ANOVA with post hoc testing revealed that civic mindedness increased in our students throughout the course of the graduate physical therapy curriculum. Analysis also supports a difference on civic mindedness between those that participated in leadership of a pro bono clinic compared with students who did not.

Discussion and Conclusion

Students involved in service-learning coursework imbedded throughout a graduate physical therapy program had increases in civic-mindedness. Servicelearning coursework may be an effective way to develop civic mindedness in graduate students.
\end{abstract}

Key Words: Civic Mindedness, Civic Minded Professional Scale, ServiceLearning

Journal of the Scholarship of Teaching and Learning, Vol. 17, No. 4, October 2017. josotl.indiana.edu 
Colleges and universities have an obligation to educate graduate students who demonstrate civic literacy and who can engage in civic inquiry and action (National Task Force on Civic Learning and Democratic Engagement, 2012). Civic-mindedness refers to a quality of someone who is knowledgable and committed to a community and who values his or her role as a member of that community (Pike, Bringle, \& Hatcher, 2014). Employers value a workforce that is highly skilled, while at the same time is high in the quality of civic-mindedness (Torney-Purta, Cabrera, Roohr, Liu, \& Rios, 2015). A civic-minded professional is someone with professional skills acquired through formal education who acts ethically and can work collaboratively with others to achieve the common good (Bringle \& Steinberg, 2010). Thus one goal of post-secondary education should be to foster civic-mindedness in their students so that they can function effectively in the $21^{\text {st }}$ century workforce.

Service-learning and community engagement courses are highly effective in developing civic-mindedness (Crandall, Wiegand, \& Brosky, 2013; Smith, Yoon, Johnson, Natarajan, \& Beck, 2014; Steinberg, Hatcher \& Bindle, 2011). The definition of service learning is "a course-based educational experience in which students: a) participate in an organized community service activity that meets identified community needs and b) reflect on the service activity in such a way as to gain further understanding of course content, a broader appreciation of the discipline and an enhanced sense of civic responsibility" (Bringle \& Hatcher, 1995). Service-learning courses provide educationally meaningful community service with a focus on reciprocal, democratic partnerships (Saltmarsh \& Hartley, 2011). In this way, both the community partners and the students learn from one another and work together from a place of mutual respect. Service-learning thus can both foster skills in a particular field and can also serve to support the development of a sense of civic responsibility (Bringle \& Steinberg, 2010).

Graduate professional programs may have additional reasons for focusing on development of civic mindedness. Physical therapy programs are one such example. The American Physical Therapy Association (APTA) has defined seven core values for the physical therapist. The first, "Accountability" acknowledges the diverse roles of the physical therapist that impact our patients, the profession and society (APTA, 2010). The second, "Altruism" calls for physical therapists to put patients' needs above their own (APTA, 2010). The third, "Compassion/Caring" identifies compassion as a precursor to caring and caring as "the concern, empathy, and consideration for the needs and values of others" (APTA, 2010). The fourth, "Excellence" values among other things the acquisition of new knowledge (APTA, 2010). The sixth "Professional duty" is meeting professional obligations to serve patients, the profession and society (APTA, 2010). The seventh, "Social Responsibility," looks towards promoting mutual trust between physical therapists and the patients they serve (APTA, 2010). All core values have sample indicators associated with them that serve as further expressions of civic engagement. (Table 1) The APTA Code of Ethics defines eight principles that are tied to the code of ethics that call physical therapists to behave professionally and ethically, to become lifelong learners as they refine their skills and work towards meeting the healthcare needs of society (APTA, 2006). The accreditation criteria put forth by the Commission for the Accreditation of Physical Therapy Education (CAPTE) delineates the knowledge and skill acquisition required to practice as an entry-level clinician at licensure and requires that students practice physical therapy in a manner consistent with the APTA Core Values and Code of Ethics (CAPTE, 2015). An additional criterion states that students should "participate in professional and community organizations that provide opportunities for volunteerism, advocacy, and leadership" (CAPTE, 2015).

Journal of the Scholarship of Teaching and Learning, Vol. 17, No. 4, October 2017.

josotl.indiana.edu 
Table 1

Selected APTA Core Values and Some Associated Sample Indicators (CAPTE, 2015).

\begin{tabular}{|c|c|}
\hline Core Value & Sample Indicators \\
\hline Accountability & $\begin{array}{l}\text { Participating in the achievement of health } \\
\text { goals of patients/clients and society. }\end{array}$ \\
\hline Altruism & $\begin{array}{l}\text { Providing pro bono services } \\
\text { Providing physical therapy services to } \\
\text { underserved and underrepresented } \\
\text { populations. } \\
\text { Providing patient/client services that go } \\
\text { beyond expected standards of practice }\end{array}$ \\
\hline Compassion/Caring & $\begin{array}{l}\text { Being an advocate for the patient's/client's } \\
\text { needs. } \\
\text { Recognizing and refraining from acting on } \\
\text { one's social, cultural, gender and sexual } \\
\text { biases. } \\
\text { Demonstrating respect for others and } \\
\text { considers others as unique and of value. }\end{array}$ \\
\hline Excellence & $\begin{array}{l}\text { Demonstrating an investment in the } \\
\text { profession of physical therapy. } \\
\text { Demonstrating high levels of knowledge and } \\
\text { skill in all aspects of the profession. } \\
\text { Pursuing new evidence to expand knowledge. }\end{array}$ \\
\hline Professional Duty & $\begin{array}{l}\text { Facilitating each individual's achievement of } \\
\text { goals of function, health, and wellness }\end{array}$ \\
\hline Social Responsibility & $\begin{array}{l}\text { Advocating for the health and wellness needs } \\
\text { of society including access to health care and } \\
\text { physical therapy services. } \\
\text { Promoting cultural competence within the } \\
\text { profession and the larger public. } \\
\text { Promoting community volunteerism }\end{array}$ \\
\hline
\end{tabular}

Journal of the Scholarship of Teaching and Learning, Vol. 17, No. 4, October 2017. josotl.indiana.edu 
Participating in political activism.

The Widener University Institute for Physical Therapy Education (IPTE) in Chester, PA admits one cohort each summer for a three-year Doctor of Physical Therapy graduate education program. All students participate in several community engagement programs designed to address the APTA Code of Ethics and Core Values statements as well as the CAPTE criteria (APTA, 2006; APTA, 2010; CAPTE, 2015). Students in their first year participate in monthly blood pressure screens at a local low-income senior residence building and in a geriatric mobility screen as part of their Lifespan I: Adulthood class (Palombaro, Black, \& Campbell, 2014). Students in their first and second year participate in our MLK Day of Service blood pressure and mobility screens at sites throughout Chester, PA (Lattanzi, Campbell, Dole, \& Palombaro, 2011). Students in their second year of study participate in brain safety fairs for children that provide brain safety education and a properly fitting bike helmet (Pierce, Palombaro, \& Black, 2016; Pierce, Palombaro, \& Black, 2014). All students participate several times each semester in the Chester Community Physical Therapy Clinic, a student-led pro bono clinic that provides physical therapy services to uninsured and underinsured residents of Chester and the surrounding communities (Black, Palombaro, \& Dole, 2013; Palombaro, Dole, \& Lattanzi, 2011; Palombaro, Dole, \& Lattanzi, 2011b). Some students apply to serve as Student Board members for their three years of education; the Student Board is responsible for the day-to-day operations of the clinic (Black et al., 2013; Palombaro et al., 2011; Palombaro et al., 2011b). Student Board members take on additional responsibility as compared to their classmates. Those who do not apply or are not selected to become board members are assigned to one of four sites in the Chester community as part of the Community Health Practicum, providing weekly physical activity programming to either children or adults (Palombaro, Lattanzi, \& Dole, 2010; Palombaro et al., 2011). Students participating in the Community Health Practicum design, implement and evaluate physical therapy programming in their second year of education, with assistance from students in their first and third years of study (Palombaro et al., 2010). The IPTE desired to measure the development of civic-mindedness in its students in order to provide evidence that our graduates were increasing in the attributes delineated by the APTA Core Values. The purpose of this paper is 1) to measure the development of civicmindedness in a cohort of physical therapy students exposed to a variety of civic engagement programs and service-learning courses and 2) to determine if there is a difference in civicmindedness between Student Board members and their classmates.

\section{Methods}

\section{Participants}

Participants were 39 members of a cohort of graduate physical therapy students at the IPTE at Widener University. This cohort was part of a three-year curriculum that graduated in the spring of 2016.

The Civic Minded Professional Scale

Journal of the Scholarship of Teaching and Learning, Vol. 17, No. 4, October 2017.

josotl.indiana.edu 
The measurement instrument was the Civic-Minded Professional Scale (CMP), a tool designed to measure the domains of self-identity; work, career and profession; and civic attitudes, civic action, and public purpose to measure the construct of civic-mindedness (Hatcher, 2008; Hatcher, manuscript in preparation). It is a 23-item, 7-point Likert-scale survey with reported reliability and validity (Hatcher, 2008; Hatcher, manuscript in preparation) and is a shortened form the original 44 -item version. The scale ranges from strongly disagree to agree and total scores range from 23 to 161. The scale measures the five factors of Voluntary Action with six items related to volunteer activity; Identity and Calling with five items measuring satisfaction and work identity; Citizenship with four items measuring participation in civic events; Trustee of Knowledge with four items related to the an individual's valuing of education and professional expertise; and Consensus across Difference with four items measuring working with individuals from diverse backgrounds (Hatcher, manuscript in preparation). Steinberg, Hatcher and Brindle (2011) provided evidence from the literature in support of the connection between civic mindedness and high impact academic practices including service-learning, as they laid the conceptual foundation for the model of the Civic-Minded Graduate. Their work identified three inter-related components that are central to this model: identity, educational experiences, and civic experiences. Each of these components can also be found in items of the Civic-Minded Professional Scale and within the various curricular activities designed to promote civic-mindedness in this study.

\section{Survey Methodology}

Institutional Review Board at Widener University approved this research project. All students in the cohort of the Class of 2016 were required to complete the CMP at the beginning of their first professional year of study and at the end of the first, second, and final years of the didactic portion of the physical therapy curriculum. The IPTE requires completion of the CMP as part of its program outcomes. However, all students were provided with a letter of informed consent. The letter explained that the students could opt-in to the research study that would allow their CMP scales to be used as part of the project. Students were provided this letter at each point in the data collection and reminded that they could opt out at any time. All students elected to opt-in to the research portion of the survey.

Students who opted in to the research study were provided with a unique identifying code known only to one researcher (JDB). This code was placed on the front of each survey at each data collection point. Surveys for each student were placed into an envelope with the student's name on the envelope. Students removed their survey from the envelope and returned their survey only to another researcher (KMP) for input into a database. At the initial point of data collection, students also completed basic demographic information of age, sex, race and year of graduation.

\section{Data Analysis}

Data were analyzed using SPSS version 20. Descriptive statistics were performed on demographic data and on the Civic-Minded Professional Scale scores for each data collection point. A Friedman's ANOVA with Wilcoxon Signed Ranks Test post-hoc testing were performed on each data collection point for the entire class to determine if there were within-group differences for each time point. Mann-Whitney U tests were performed on CMP data to determine if betweengroup differences existed for Student Board and non-Student Board members. Effect sizes were

Journal of the Scholarship of Teaching and Learning, Vol. 17, No. 4, October 2017. josotl.indiana.edu 
calculated for all statistically significant results using the formula for Cohen's $\mathrm{D}\left(\mathrm{d}=\mathrm{X}_{1}-\mathrm{X}_{2} / \mathrm{s}_{\mathrm{p}}\right)$ (Cohen, 1988).

\section{Results}

Thirty-nine students comprised the completed cohort for the Class of 2016. Of those 39, 2 students had incomplete data on one or more surveys and were excluded from the analysis.

Descriptive statistics were run to provide a more complete picture of the cohort. The mean age was $22.4(\mathrm{SD}=1.9)$ upon entering the program. Eleven members were males and 26 were female. The cohort was comprised of 36 Caucasians and one person who identified as Hispanic/Latino. Data for the CMP is presented as means and standard deviations because the Likert-scale provided a summative score and the data were normally distributed (Hatcher, manuscript in preparation).

Non-parametric statistics were run due to the sample being one of convenience. Friedman's repeated-measures ANOVA was significant $(\mathrm{p}=.001)$ for between-group differences. Wilcoxon Signed Ranks post hoc tests were performed. Significant increases in the CMP were found between pre-test of year 1 and the post-test of year $2(p=.016$, Cohen's effect size value $d=.48)$, the pretest of year 1 and the post-test of year $3(p \leq .001$, Cohen's $d=.70)$, the post-test of year 1 and the post-test of year $2(\mathrm{p}=.008$, Cohen's $\mathrm{d}=.53)$ and the post-test of year 1 and the post-test of year $3(\mathrm{p} \leq .001$, Cohen's $\mathrm{d}=.70)$. The effect sizes ranged from $.48-.70$ suggesting moderate to high practical significance (Cohen, 1988). (Table 2)

Table 2

Descriptive Statistics for the Civic-Minded Professional Scale for the Entire Class at Each Assessment Point.

\begin{tabular}{|c|c|c|}
\hline Test Time & Mean & SD \\
\hline Pre-test Year 1 & 120.5 & 13.8 \\
\hline Post-test Year 1 & 119.9 & 12.8 \\
\hline Post-test Year 2 & 127.6 & 11.9 \\
\hline Post-test Year 3 & 130.2 & 12.0 \\
\hline
\end{tabular}

Mann-Whitney U testing was performed to determine if there were differences between Student Board and non-Student Board members at each assessment point. A significant difference was found for the year three post-test $(\mathrm{p}=.04$, Cohen's $\mathrm{d}=.58)$. The effect size suggests moderate practical significance (Cohen, 1988). (Table 3.)

Journal of the Scholarship of Teaching and Learning, Vol. 17, No. 4, October 2017.

josotl.indiana.edu 
Table 3

Means and Standard Deviations for Student Board and Non-Student Board Members at Each Assessment Point

\begin{tabular}{|c|c|c|c|c|}
\hline Test Time & \multicolumn{2}{|c|}{ Student Board } & \multicolumn{2}{c|}{ Non-Student Board } \\
\hline & Mean & SD & Mean & SD \\
\hline Pre-test Year 1 & 119.10 & 11.45 & 121.12 & 14.79 \\
\hline Post-test Year 1 & 117.90 & 9.17 & 120.76 & 14.12 \\
\hline Post-test Year 2 & 129.20 & 11.46 & 126.92 & 12.28 \\
\hline Post-test Year 3 & 134.80 & 9.10 & 128.36 & 12.65 \\
\hline
\end{tabular}

\section{Discussion}

Our results indicate that civic mindedness increased in our students throughout the course of the graduate physical therapy curriculum. We propose that this increase may be due to the students' exposure to service-learning coursework and programming that was directly tied to skills needed to become a physical therapist, although other factors could also influence this change. Community-based service learning is a structured experience with defined learning objectives, effective preparation and reflection. Community-based service learning places a focus on development of citizenship and reciprocal learning on the part of the students and the community partner (Seifer, 1998). All service-learning activities at the IPTE require that the students interact with community members in meaningful ways. They serve to interview and educate community members. Within the geriatric screens and the MLK Day of Service, they are making direct application of specific physical therapy screenings. The Community Health Practicum requires that the students educate participants on the importance of physical activity to maintain or improve health. Finally, as the students participate in the student-run pro bono clinic, they are participating in client care to the extent that their skills allow. For example, first-year students take vital signs and conduct client interviews. They begin to participate in interventions regarding mobility and exercise. Second year students begin to conduct evaluations with newly acquired assessment and documentation skills. Third year students apply more complex manual and neuromotor skills as well as supervise second and first year students in client programs. This all occurs under the direct supervision of licensed physical therapists. Hence, all of the service-learning and community engagement activities within the IPTE engage the students in meaningful physical therapy-related skills and interactions with actual community members. As they do so, they are developing relationship and rapport with the community members and gaining a perspective on the overall impact that culture, lifestyle, and community have on the physical therapy encounter. Hence, service-learning may be a powerful experience for fostering civic-mindedness.

Service-learning coursework may foster professional skills development (Brosky, Deprey, Hopp, \& Maher, 2006). Gupta (2006) found that students who participate in service learning are more likely to continue to perform service after graduation. In a sample of medical students participating in a student-run free clinic, students gained greater knowledge and skills, and improved their attitude towards underserved patient populations and developed greater interest in working with this patient population (Smith, Yoon, Johnson, Natarajan, \& Beck, 2014). Qualitative research examining student perceptions after working in a pro bono physical therapy

Journal of the Scholarship of Teaching and Learning, Vol. 17, No. 4, October 2017.

josotl.indiana.edu 
clinic uncovered themes of core values, development of clinical physical therapy skills, professional growth and professional connections (Stickler, Grapczynski, \& Ritch, 2013).

Crandall, et al. (Crandall, Wiegand, \& Brosky, 2013) studied 91 DPT students involved in service-learning courses through interviews, examination of reflection papers and the APTA Core Values Self-Assessment survey. The survey identified themes of accountability and compassion/caring. Student interviews identified the core value of compassion/caring as the strongest with accountability, altruism and professional duty also occurring frequently. The reflection papers yielded themes of compassion/caring, social responsibility, and professional duty. Findings from Wise and Yuen (2013) examined the impact of community-based service-learning on DPT students. Students demonstrated a positive trend on all core values with significant increases in altruism, compassion/caring, and integrity. While the present study used the CMP versus the APTA Core Values Self-Assessment survey, it is our belief that APTA core values are elements of civic-mindedness. The present study corroborates the evidence that participation in pro bono service and service-learning classes appears to promote the development of civicmindedness in graduate physical therapy students.

Overall, students who had taken on additional responsibilities of overseeing the pro bono clinic operations did not demonstrate significantly higher civic-mindedness as compared to other students at the beginning of the curriculum or at the end of their first and second year. This signifies that students who were attracted to Student Board membership were not significantly different from their non-Student Board peers at the beginning of the curriculum and that the first and second year experiences did not differ for these students in terms of civic mindedness development. The authors see this as a positive and important finding. The student board is one means to improving civic mindedness, but is not the only means within the IPTE curriculum. Students take on leadership in the community through the Community Health Practicum or the Student Board and all students serve in the clinic as student physical therapists. These findings show that while students experience different opportunities to develop civic-mindedness, overall these opportunities created similar outcomes.

Student Board members did exhibit significantly higher civic-mindedness at the end of the third year of the didactic curriculum. The authors believe this may be due to the increased exposure Student Board members have to making professional presentations in their third year at the APTA National Student Conclave, the Pennsylvania Physical Therapy Association Conference, APTA Combined Sections meeting and the Student Run Free Clinic Conference, although first and second-year Student Board members begin to participate in these experiences as well. Bringle et al (2011) define a key element of a Civic Minded Graduate as having listening and communication skills, which includes activities such as spoken communication as well as letter writing and professional presentations. Other disciplines such as business (Tucker \& McCarthy, 2001), pharmacy, (Osborne, Hammerich, \& Hensley, 1998) and conservation biology (Clark, 2001) describe professional presentations as one area that can assist in the development of civic mindedness. For example, Clark (2011) states that aligning educational programs with the Society for Conservation Biology objectives to increase research and professional dissemination of results will foster civic mindedness in graduates. Tucker and McCarthy (2001) found increased confidence in presentation ability was significantly related to business students enrolled in a service-learning course as compared to students enrolled in a traditional section of the same course. With these findings in mind, all students should be given opportunities for professional presentations in the coming years.

Journal of the Scholarship of Teaching and Learning, Vol. 17, No. 4, October 2017.

josotl.indiana.edu 
This study had several limitations. The first is that we cannot control for experiences outside of the service learning experiences that may have increased civic-mindedness such as nonprofessional volunteer work (e.g. being a Big Brother/Big Sister, coaching etc). Additionally, this is representative of a single cohort of students and for which no control group was available for comparison. Lack of a control to understand the natural progression of civic mindedness in DPT students who do not experience service learning and civic engagement limits the interpretation of these findings. Research and replication of this work with future classes across the curriculum and the potential addition of professional presentation experiences for all students may also provide improved clarity on the present study's finding. Finally, the CMP is a self-report scale. Selfassessment is a skill that is developed as part of a physical therapy curriculum (Musolino, 2006), thus self-assessment may become more reliable at each measurement point.

\section{Conclusion}

In conclusion, service-learning coursework and community engagement experiences imbedded throughout a graduate physical therapy program may be an important factor in increasing in student civic-mindedness. The students in this study demonstrated consistent increases in civicmindedness as measured by the Civic-Minded Professional Scale. Students participating in leadership experiences related to a student-run pro bono clinic had changes in civic-mindedness that significantly exceeded the changes exhibited by students who did not engage in those additional opportunities.

\section{Acknowledgement}

The authors wish to acknowledge grant support from the Widener University Faculty Development and Provost Grant programs.

Journal of the Scholarship of Teaching and Learning, Vol. 17, No. 4, October 2017.

josotl.indiana.edu 


\section{References}

APTA. Code of ethics. (2006). (No. HOD S06-09-07-12). Alexandria, VA: American Physical Therapy Association. Retrieved from http://www.apta.org/Ethics/Core/

APTA. (2010). Professionalism in physical therapy: Core values. Retrieved from http://www.ptcas.org/Professionalism/

Black, J. D., Palombaro, K. M., \& Dole, R. L. (2013). Student experiences in creating and launching a student-led physical therapy pro bono clinic: A qualitative investigation. Physical Therapy, 93(5), 637-648. https://doi.org/10.2522/ptj.20110430

Bringle, R. G., \& Hatcher, J. A. (1995). A service-learning curriculum for faculty. Michigan Journal of Community Service Learning, 2, 112-122.

Bringle, R. G., \& Steinberg, K. (2010). Educating for informed community involvement. American Journal of Community Psychology, 46 (3-4), 428-441. https://doi.org/10.1007/s10464010-9340-y

Bringle, R. G., Studer, M., Wilson, J., Clayton, P. H., \& Steinberg, K. (2011). Designing programs with a purpose: To promote civic engagement for life. Journal of Academic Ethics, 9, 149-164. https://doi.org/10.1007/s10805-011-9135-2

Brosky, J. A., Deprey, S. M., Hopp, J. F., \& Maher, E. J. (2006). Physical therapist student and community partner perspectives and attitudes regarding service-learning experiences. Journal of Physical Therapy Education, 20(3), 41-48.

Clark, T. W. (2001). Developing policy-oriented curricula for conservation biology: Professional and leadership education in the public interest. Conservation Biology, 15(1), 31-39. https://doi.org/10.1111/j.1523-1739.2001.99007.x

Cohen J. (1988). Statistical power analysis for the behavioral sciences. Hillsdale, NJ: Erlbaum Associates.

Commission on Accreditation in Physical Therapy Education (CAPTE). PT standards with evidence. (2015). Retrieved from http://www.capteonline.org/AccreditationHandbook/

Crandall, C. E., Wiegand, M. R., \& Brosky, J. A. (2013). Examining the role of service-learning on development of professionalism in doctor of physical therapy students: A case report. Journal of Allied Health, 42(1), e25-e32.

Hatcher, J. A. Developing and evaluating the civic-minded professional scale. Manuscript in preparation.

Hatcher, J. A. (2008). The public role of professionals: Developing and evaluating the civicJournal of the Scholarship of Teaching and Learning, Vol. 17, No. 4, October 2017. josotl.indiana.edu 
minded professional scale.. (Unpublished $\mathrm{PhD}$ ). Indiana University, Indianapolis, IN.

Lattanzi, J. B., Campbell, S. L., Dole, R. L., \& Palombaro, K. M. (2011). Students mentoring students in a service-learning clinical supervision experience: An educational case report. Physical Therapy, 91(10), 1513-1524. https://doi.org/10.2522/ptj.20100308

Musolino, G. M. (2006). Fostering reflective practice: Self-assessment abilities of physical therapy students and entry-level graduates. Journal of Allied Health, 35(1), 30-42.

National Task Force on Civic Learning and Democratic Engagement. (2012). A crucible moment: College learning and democracy's future. Washington, DC: Association of American Colleges and Universities.

Osborne, R. E., Hammerich, S., \& Hensley, C. (1998). Student effects of service-learning: Tracking change across a semester. Michigan Journal of Community Service Learning, 5, 5-13.

Palombaro, K. M., Black, J. D., \& Campbell, S. L. (2014). Geriatric screening as an educational tool: A case report. Journal of Physical Therapy Education, 28(2), 54-50.

Palombaro, K. M., Dole, R. L., \& Lattanzi, J. B. (2011). The development of a community clinic: How a signature project can mobilize commitment to sustainable community. In M. W. Ledoux, S. C. Wilhite \& P. Silver (Eds.), Civic engagement and service learning. (1st ed., pp. 90-108). Hauppauge, NY: Nova Science Publishers, Inc.

Palombaro, K. M., Dole, R. L., \& Lattanzi, J. B. (2011b). A case report of a student-led pro bono clinic: A proposed model for meeting student and community needs in a sustainable manner. Physical Therapy, 91(11), 1627-1635. https://doi.org/10.2522/ptj.20100437

Palombaro, K. M., Lattanzi, J. B., \& Dole, R. L. (2010). Creating sustainable community engagement initiatives in a graduate physical therapy program. Metropolitan Universities, May, 61-75.

Pierce, S. R., Palombaro, K. M., \& Black, J. B. (in press). Brain safety fair. Alexandria, VA: APTA.

Pierce, S. R., Palombaro, K. M., \& Black, J. D. (2014). Barriers to bicycle helmet use in young children in an urban elementary school. Health Promotion Practice, 15(3), 406-412. https://doi.org/10.1177/1524839913512329

Pike, G. R., Bringle, R. G., \& Hatcher, J. A. (2014). Assessing civic engagement at Indiana University-Purdue University Indianapolis. New Directions for Institutional Research, 162, 8797. https://doi.org/10.1002/ir

Saltmarsh, J., \& Hartley, J. M. (2011). To serve a larger purpose: Engagement for democracy and the transformation of higher education. Philadelphia, PA: Temple University Press.

Journal of the Scholarship of Teaching and Learning, Vol. 17, No. 4, October 2017. josotl.indiana.edu 
Seifer, S. D. (1998). Service-learning: Community-campus partnerships for health professions education. Academic Medicine: Journal of the Association of American Medical Colleges, 73(3), 273-277. https://doi.org/10.1097/00001888-199803000-00015

Smith, S. D., Yoon, R., Johnson, M. L., Natarajan, L., \& Beck, E. (2014). The effect of involvement in a student-run free clinic project on attitudes toward the underserved and interest in primary care. Journal of Health Care for the Poor and Underserved, 25(2), 877-889. https://doi.org/10.1353/hpu.2014.0083

Steinberg, K. S., Hatcher, J. A., \& Bindle, R. G. (2011) Civic-minded graduate: A north star. Michigan Journal of Community Service Learning, 18, 19-33.

Stickler, L., Grapczynski, C., \& Ritch, J. (2013). Student perceptions of outcomes from participation in physical therapy pro bono clinics. Journal of Allied Health, 42(1), 46-55.

Torney-Purta, J., Cabrera, J. C., Roohr, K. C., Liu, O. L., \& Rios, J. A. (2015). Assessing civic competency and engagement in higher education; research background, frameworks, and directions for next-generation assessment. (No. RR-15-34). https://doi.org/10.1002/ets2.12081

Tucker, M. L., \& McCarthy, A. M. (2001). Presentation self-efficacy: Increasing communication skills through service-learning. Journal of Managerial Issues, 13(2), 227-245.

Wise, H. H., \& Yuen, H. K. (2013). Effect of community-based service learning on professionalism in student physical therapists. Journal of Physical Therapy Education, 27(2), 5864.

Journal of the Scholarship of Teaching and Learning, Vol. 17, No. 4, October 2017.

josotl.indiana.edu 